\title{
Chalcogenide Thin Film Substrate for Protein Biochip Application
}

\author{
A. S. Tveryanovich, ${ }^{1}$ A. S. Vasileva, ${ }^{1}$ A. V. Belykh, ${ }^{2}$ E. N. Borisov, ${ }^{1}$ and Yu. S. Tveryanovich ${ }^{1}$ \\ ${ }^{1}$ Department of Chemistry, Saint Petersburg State University, Universitetskii Prospekt 26, Petrodvorets, Saint Petersburg 198504, Russia \\ ${ }^{2}$ JSC HoloGrate, Prospekt Rimskogo-Korsakova 45, Saint Petersburg 190068, Russia \\ Correspondence should be addressed to A. S. Tveryanovich; andr.tver@yahoo.com
}

Received 30 October 2013; Accepted 17 January 2014; Published 5 March 2014

Academic Editor: Ioana Demetrescu

Copyright (c) 2014 A. S. Tveryanovich et al. This is an open access article distributed under the Creative Commons Attribution License, which permits unrestricted use, distribution, and reproduction in any medium, provided the original work is properly cited.

Diagnostic of pathogen in the human biological liquids by biochip technology is an intensively developed methodic now. The main and the most important part of biochip is the adsorbing layer. Adsorption properties of chalcogenide films to protein (rat monoclonal antibodies) were tested. The films were prepared by conventional thermal deposition technique and by pulsed laser deposition technique. Two methods were used for forming in the films the two-dimensional map of adsorbing places for probe testing. One is using photoresist properties of chalcogenide films; another is using photo-induced oxidation of chalcogenide films. It was shown Good selectivity of the developed structures to protein markers was shown.

\section{Introduction}

Diagnostic of pathogen in the human biological liquids by biochip technology is an intensively developed methodic now. The most important part of biochip is the adsorbing layer.

There are two main problems in developing this layer. One is creation of pattern on the film-surface and the second is achievement of selectivity of adsorption of protein or DNA to the created pattern [1]. Chalcogenide glasses have ability to adsorb biological materials [2]. Besides, chalcogenide glasses, for example, of the As-S system have photostructural transformations under irradiation of light with energy above band gap [3]. These transformations are characterized by changes in the chemical short-range structure and some properties. It can be used for creation of precision island structure with photoresist technology. Also, Ge-Ga-S glassy films undergo photo-induced oxidation under exposure to photons with energy above the band gap [4]. It results in fundamental changes in the chemical structure. Both these effects can be used for forming two-dimensional map of places for adsorbing of probe at the films taking into account supposition that chalcogenide and oxide glasses have different ability to adsorb amine groups of proteins or DNA.

Methods of patterning and adsorption properties of chalcogenide films to protein or DNA were investigated in this work for the biochip application.

\section{Experimental}

The glasses of $\mathrm{As}_{39} \mathrm{~S}_{61}$ and $\mathrm{Ge}_{26} \mathrm{Ga}_{9} \mathrm{~S}_{65}$ compositions were synthesized in evacuated quartz ampoules from elementary arsenic and sulfur or elementary germanium, gallium, and sulfur. The prepared $\mathrm{As}_{39} \mathrm{~S}_{61}$ glass was used to deposition of thin films onto standard glass slide by thermal deposition. The film thickness was about $500 \mathrm{~nm}$. The synthesized $\mathrm{Ge}_{26} \mathrm{Ga}_{9} \mathrm{~S}_{65}$ glass was used for preparation of the thin films by pulsed laser deposition (XeCl laser was used). Pulsed laser deposition from one rotating target (pies of glass) leaded to formation of film with nonuniform surface geometry. Therefore, the special target consisting of 12 glass pieces arranged in a circle at different angles to the laser beam was used. During laser ablation, the target revolved permanently, 


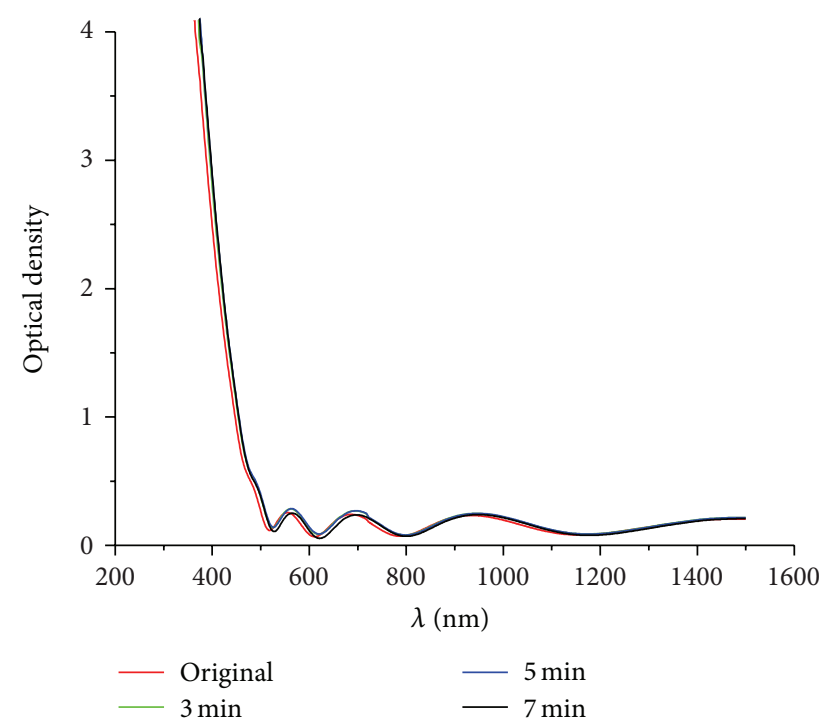

(a)

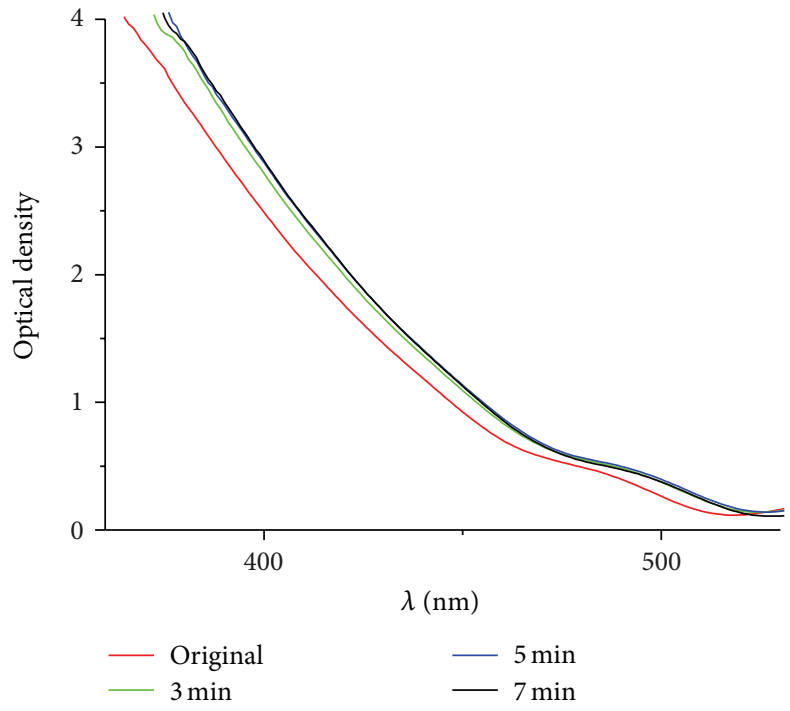

(b)

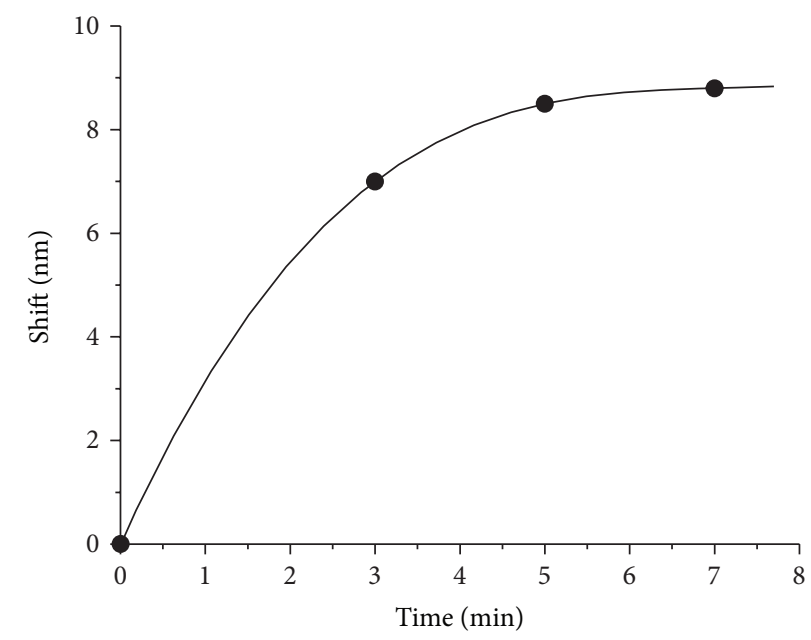

(c)

FIgure 1: (a) and (b) The absorption spectra of $\mathrm{As}_{39} \mathrm{~S}_{61}$ films. The source film and the irradiated films for 3, 5, and 7 minutes. (c) The dependence of the shift of the fundamental absorption edge of $\mathrm{As}_{39} \mathrm{~S}_{61}$ film on exposition time.

so the plasma stream changed permanently its angle relative to the substrate, increasing the uniformity of the surface of the deposited film [5].

The mercury lamp was used for UV irradiation of the deposited films. For test of the adsorbing ability, the following protein and DNA materials marked with fluorescent labels were used: green recombinant protein (EGFP) (1:20 and $1: 200$ dilution); pure hemagglutinin derived from the influenza virus type $\mathrm{A}$, conjugated to a fluorescent label Cy3 (HA-Cy3) (1:10 and 1:100); mouse antibody to rabbit immunoglobulins conjugated to a fluorescent label Cy5 (RAM-Cy5) (1:100 and 1:1000); mouse antibody to rabbit immunoglobulins conjugated to a fluorescent label Cy3 (RAM-Cy3) (1:100 and 1:1000); labeled amplicon prepared by PCR with the nucleotide dCTP-Cy5 (DNA-Cy5) $(1: 100$ and 1:1000); short probe with $\mathrm{NH}_{2}$ group at the $5^{\prime}$-end and marker $\mathrm{Cy} 3$ at the $3^{\prime}$-end (NNMolig-Cy3) $(1: 1000$ and 1:10000); short probe $\mathrm{NH}_{2}$ group at the $5^{\prime}$-end and marker Cy5 at the $3^{\prime}$-end (NNMolig-Cy5) $(1: 1000$ and $1: 10000)$.

\section{Experimental Data and Discussion}

The kinetic of photostructural transformation was studied to optimize the irradiation conditions of the films. Thus, the changing of the fundamental absorption edge position of the film after irradiation with UV light was investigated. The optical absorption spectra of the source film and the irradiated films for 3, 5, and 7 minutes are shown in Figures 1(a) and 1(b). 


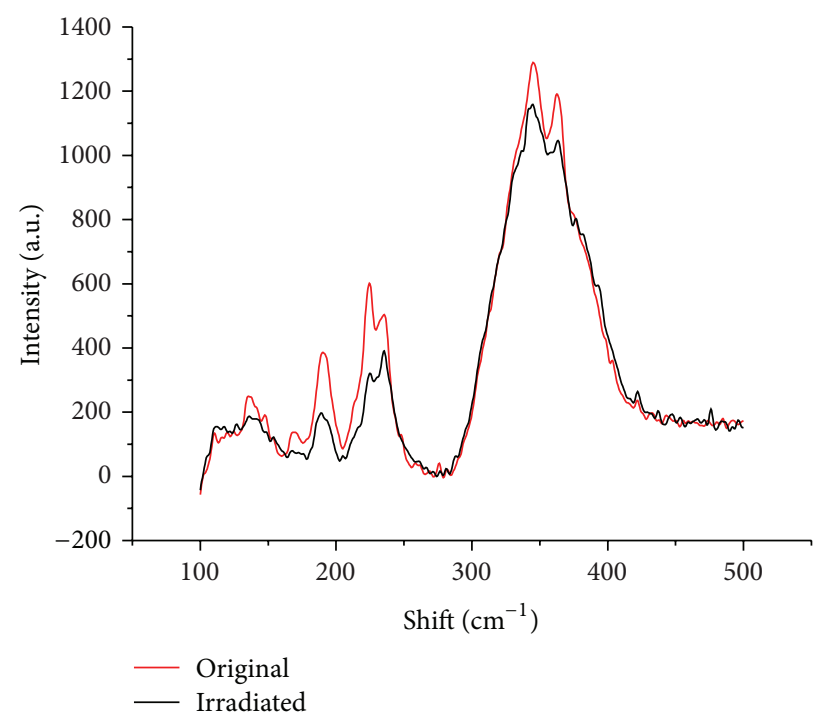

FIgURE 2: The Raman spectra of the $\mathrm{As}_{39} \mathrm{~S}_{61}$ film, source film, and the irradiated film for 7 minutes.
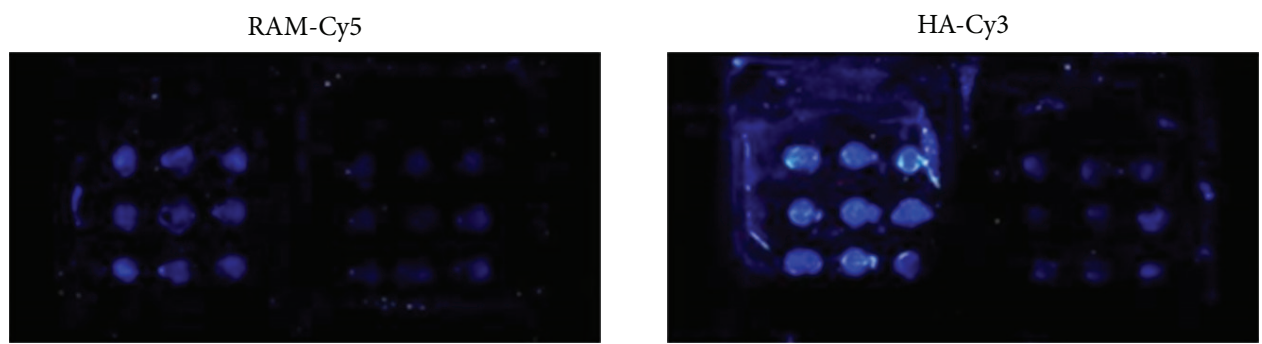

NNMolig-Cy

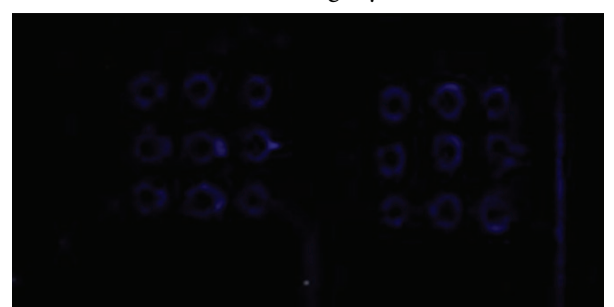

FIgURE 3: Fluorescent image of subarrays with chalcogenide glass film islands treated with RAM-Cy5, HA-Cy3, and NNMolig-Cy5.

According to the dependence shown in Figure 1(c), the photo-induced darkening effect (shift of the fundamental absorption edge toward longer wavelengths) reaches saturation after 5 minutes of exposure. This shift has value of about $10 \mathrm{~nm}$. At the same time there is a change in the chemical structure of the film, which is reflected in the Raman spectra. Figure 2 shows the Raman spectra of the source film and the film after irradiation.

Decreasing intensity of the peaks at wavenumbers 364 , 345,223 , and $191 \mathrm{~cm}^{-1}$ (which belong to $\mathrm{As}_{4} \mathrm{~S}_{4}$ structure units testifies decreasing concentration of these structure units) relatively the basic structural units $\mathrm{AsS}_{3 / 2}[6,7]$. Existence of defect $\mathrm{As}_{4} \mathrm{~S}_{4}$ structure units in the as-deposited film is due to disproportionation $\mathrm{As}_{2} \mathrm{~S}_{3}$ compound in the vapor phase [8]. Thus, the irradiation of the film leads to relaxation of the chemical structure and to reducing relative fraction of homobonds that should be manifested in the change of the etching rate of the film. Reaction of dissolution $\mathrm{As}_{2} \mathrm{~S}_{3}$ glass in amine solvents is the following [9]:

$$
\mathrm{As}_{2} \mathrm{~S}_{3}+6 \mathrm{R}_{2} \mathrm{NH}=\left(\mathrm{RNH}_{2}\right)_{3} \mathrm{AsS}_{3}+\mathrm{As}\left(\mathrm{R}_{2} \mathrm{~N}\right)_{3},
$$

while reactions of dissolution glass film with high concentration $\mathrm{As}_{4} \mathrm{~S}_{4}$ and $\mathrm{S}_{n}$ structure units in amine solvents are the following [9]:

$$
\begin{gathered}
\mathrm{R}_{2} \mathrm{NH}+\mathrm{S}_{n}=\mathrm{R}_{2} \mathrm{~N}^{+} \mathrm{HS}_{n}^{-}, \\
\mathrm{R}_{2} \mathrm{~N}^{+} \mathrm{HS}_{n}^{-}+\mathrm{As}_{2} \mathrm{~S}_{4 / 2}=\mathrm{R}_{2} \mathrm{NAsS}_{2 / 2}+\mathrm{R}_{2} \mathrm{~N}^{+} \mathrm{H}_{2} \mathrm{~S}^{-} \mathrm{AsS}_{2 / 2} .
\end{gathered}
$$

The above-mentioned results were used in order to create the test microarray. The deposited $\mathrm{As}_{39} \mathrm{~S}_{61}$ film was irradiated with UV light through a mask (opaque shield 


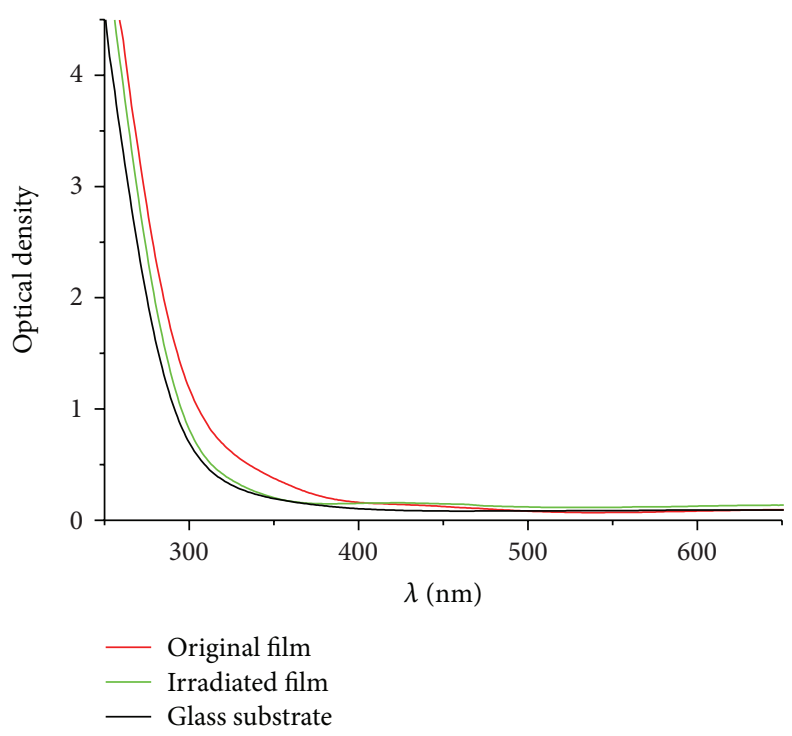

FIGURE 4: The absorption spectra of the glass slide, source $\mathrm{Ge}_{26} \mathrm{Ga}_{9} \mathrm{~S}_{65}$ film, and the film irradiated for 20 minutes.
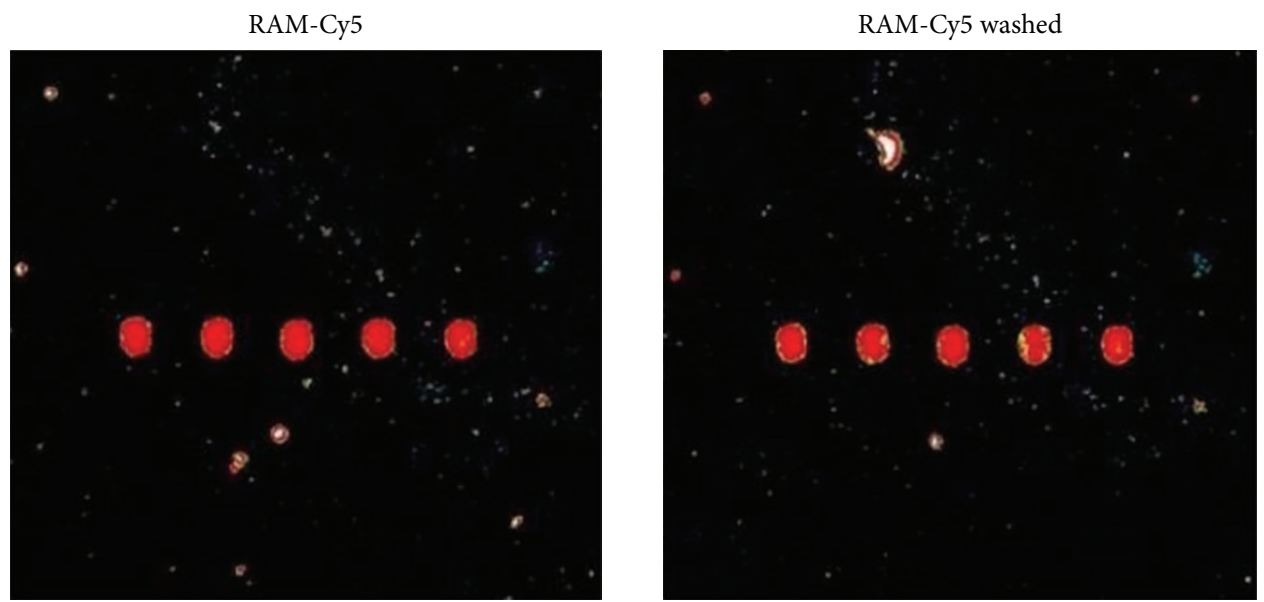

FIGURE 5: Fluorescent image of RAM-Cy5 deposited onto $\mathrm{Ge}_{26} \mathrm{Ga}_{9} \mathrm{~S}_{65}$ chalcogenide film. Left image is film with deposited RAM-Cy5; right image is the same film washed after that.

with 16 subarrays that consist of 9 holes (array $3 \times 3)$ ) and etched under the above-mentioned conditions. Mixture of $75 \%$ triethylphosphate and $25 \%$ dipentylamine was used as the etching solution. It leaded to glass slide on which chalcogenide glassy wheels were formed in the defined order.

After that the prepared substrates (glass slide with chalcogenide glass islands) were washed $15 \mathrm{~min}$ in a solution of $1 \mathrm{x}$ PBS-T (concentration of Tween 20 was $0.05 \%$ ) and scanned at wavelengths of fluorescence of the three markers-Cy3 $(582 \mathrm{~nm})$, Cy5 $(664 \mathrm{~nm})$ and GFP $(509 \mathrm{~nm})$. All dilutions of the protein samples were prepared in 1x PBS. DNA samples were diluted in Milli-Q water. All 16 subarrays were divided with special frames. $100 \mathrm{mcl}$ of a protein or DNA solution was applied to each subarray on the substrate. Then it was treated for 1 hour at $37^{\circ} \mathrm{C}$ on shaker PST-60 HL Plus (Biosan). After that, it was washed from unbound molecules 2 times for $5 \mathrm{~min}$ in PBS-T; then frames were removed and the whole substrate was washed for 5 minutes in Milli-Q water. The prepared substrate was scanned on a fluorescent scanner Scan Array Express ("PerkinElmer", USA) with the following parameters: PMT 70, RES 20. The excitation and scanning wavelengths depended on the used fluorescent marker.

For example, fluorescent images of subarrays of chalcogenide glass islands onto oxide glass slide treated with RAMCy5 and HA-Cy3 are shown in Figure 3. It testifies adsorption of proteins by chalcogenide film. In the same time, $\mathrm{As}_{39} \mathrm{~S}_{61}$ glass film had low adsorption ability to DNA. Example with NNMolig-Cy5 is shown in Figure 3.

The kinetic of photooxidation of the deposited $\mathrm{Ge}_{26} \mathrm{Ga}_{9} \mathrm{~S}_{65}$ films was studied with optical absorption spectroscopy. Irradiation of the deposited film with mercury lamp for $20 \mathrm{~min}$ results in saturation of the photooxidation effect. Figure 4 shows the absorption spectra of the source and the irradiated films. 
Adsorption ability of the irradiated and nonirradiated areas of the films to protein and DNA was investigated. The first preliminary results were obtained. The ability of the prepared $\mathrm{Ge}_{26} \mathrm{Ga}_{9} \mathrm{~S}_{65}$ film to adsorb protein molecules was evaluated using microarray technology. Proteins marked with fluorescent markers (RAM-Cy5, HA Cy3, and GFP) in concentration 1:100 were printed on the film. Then film was scanned with fluorescent scanner ScanArray Express. After that, film was washed for 5 minutes in a buffer solution 1xPBS with stirring and then film was scanned again. As result, all the tested proteins were adsorbed on the chalcogenide films. For example, fluorescent images of the film with printed RAM-Cy 5 before and after washing treatment are shown in Figure 5.

\section{Conclusions}

In this way we created the test methods of patterning from chalcogenide glassy thin film and demonstrated the presence of selective adsorption of protein markers to such structures. The obtained data shows the perspective for the use of chalcogenide films as substrates for biochips with spatially defined selective adsorption of biological probes.

\section{Conflict of Interests}

The authors declare that there is no conflict of interests regarding the publication of this paper.

\section{Acknowledgments}

This work was supported by Grant of St. Petersburg State University no. 12.39.1047.2012.

\section{References}

[1] P. Lucas, M. A. Solis, D. L. Coq et al., "Infrared biosensors using hydrophobic chalcogenide fibers sensitized with live cells," Sensors and Actuators B, vol. 119, no. 2, pp. 355-362, 2006.

[2] T. Ekblad and B. Liedberg, "Protein adsorption and surface patterning," Current Opinion in Colloid \& Interface Science, vol. 15, no. 6, pp. 499-509, 2010.

[3] J. P. De Neufville, S. C. Moss, and S. R. Ovshinsky, "Photostructural transformations in amorphous $\mathrm{As}_{2} \mathrm{Se}_{3}$ and $\mathrm{As}_{2} \mathrm{~S}_{3}$ films," Journal of Non-Crystalline Solids, vol. 13, no. 2, pp. 191-223, 1974.

[4] S. H. Messaddeq, M. S. Li, S. Inoue, S. J. L. Ribeiro, and Y. Messaddeq, "Photoinduced effect in Ga-Ge-S based thin films," Applied Surface Science, vol. 252, no. 24, pp. 8738-8744, 2006.

[5] A. Tverjanovich, E. N. Borisov, E. S. Vasilieva et al., "CuInSe2 thin films deposited by UV laser ablation," Solar Energy Materials and Solar Cells, vol. 90, no. 20, pp. 3624-3632, 2006.

[6] D.-Y. Choi, S. Madden, R. P. Wang, A. Rode, M. Krolikowska, and B. Luther-Davies, "Nano-phase separation of arsenic trisulphide $\left(\mathrm{As}_{2} \mathrm{~S}_{3}\right)$ film and its effect on plasma etching," Journal of Non-Crystalline Solids, vol. 353, no. 8-10, pp. 953-955, 2007.

[7] S. Mamedov, D. G. Georgiev, T. Qu, and P. Boolchand, "Evidence for nanoscale phase separation of stressed-rigid glasses," Journal of Physics Condensed Matter, vol. 15, no. 31, pp. S2397S2411, 2003.
[8] A. A. Popescu, D. Savastru, M. Ciobanu, S. Miclos, and V. T. Dolghier, "Mass-spectrometric studies of vitreous $\mathrm{As}_{2} \mathrm{~S}_{3}$," Journal of Optoelectronics and Advanced Materials, vol. 13, no. 9, pp. 1193-1198, 2011.

[9] S. A. Zenkin, S. B. Mamedov, M. D. Mikhailov, E. Y. Turkina, and I. Y. Yusupov, "Mechanism for interaction of amine solutions with monolithic glasses and amorphous films in the As-S system," Glass Physics and Chemistry, vol. 23, no. 5, pp. 393-399, 1997. 

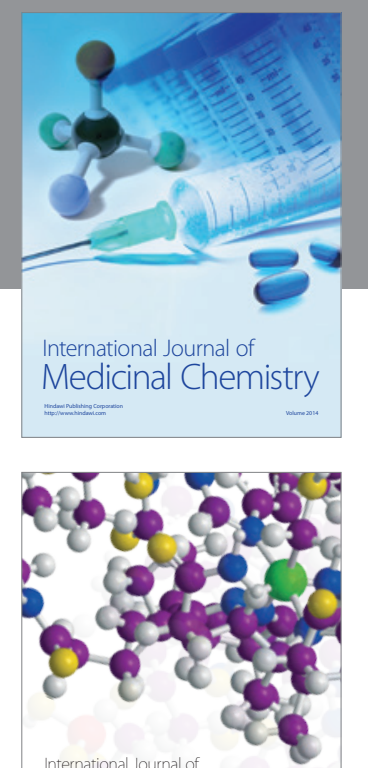

\section{Carbohydrate} Chemistry

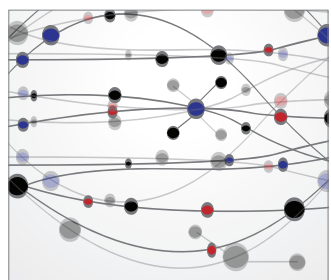

The Scientific World Journal
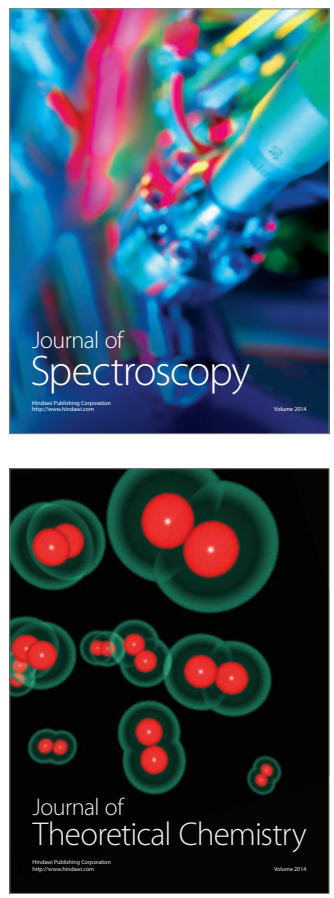
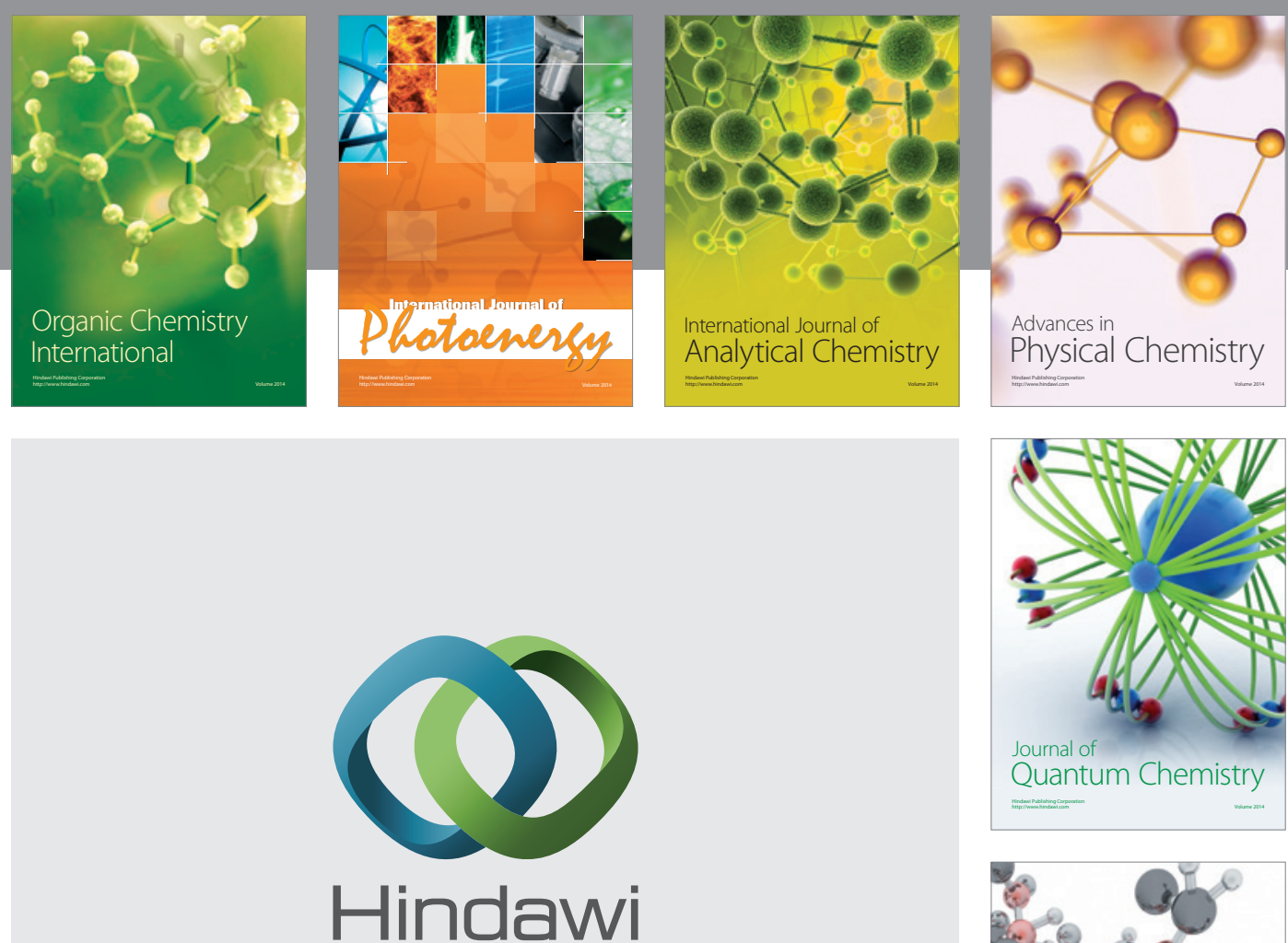

Submit your manuscripts at

http://www.hindawi.com

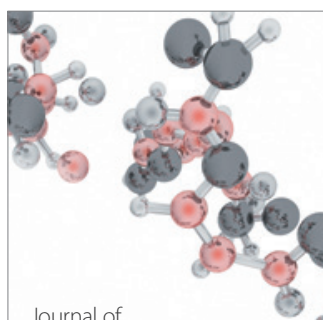

Analytical Methods

in Chemistry

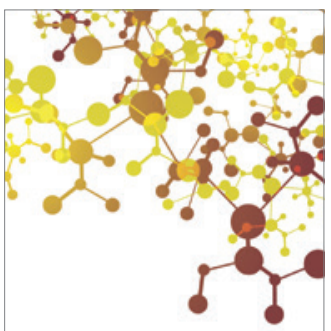

Journal of

Applied Chemistry

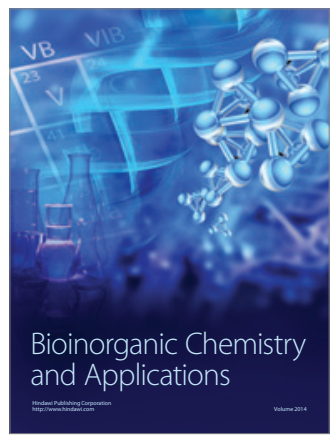

Inorganic Chemistry
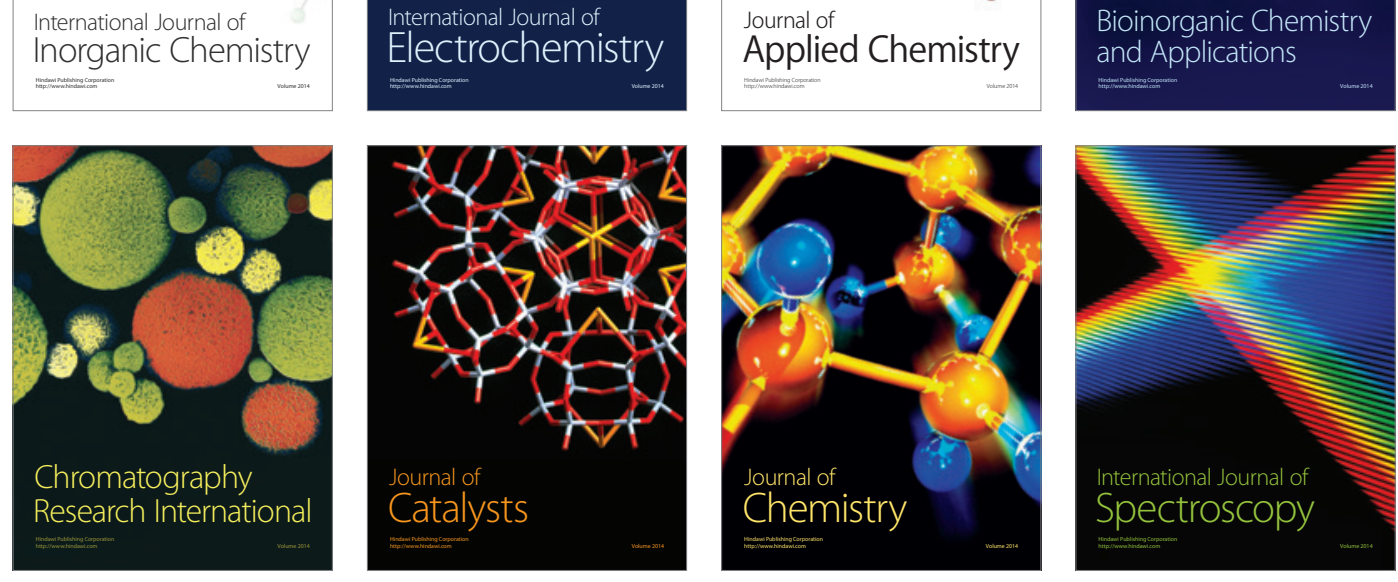